\title{
MATING DIOECIOUS SYSTEM OF CIRSIUM ARVENSE (L.) SCOP. WEED
}

\author{
Nicolaie Ionescu ${ }^{1 *}$, Oana Badea ${ }^{1}$, Magdalena Podea ${ }^{1}$, Diana Popescu ${ }^{1}$, Cristina Ghiorghe ${ }^{1}$, \\ Mariana Nicolaie ${ }^{1}$, Cătălin Dinuță ${ }^{1}$, Robert Gheorghe ${ }^{1}$ \\ ${ }^{1}$ Agricultural Research and Development Station Pitești, \\ Piteşti-Slatina road km. 5, 117030, Piteşti, România
}

\section{Current Trends in}

\section{Natural Sciences}

\begin{abstract}
The species has an important presence in crops (Everitt et al., 2007). It's occurs in- micro (asexually) by forming clones with different densities (Donald, 1994), and in-macro (sexually) by fruits with conquering new lands. The sexed propagation type is dioecious, with the presence of both female plants and those male. To express existent ecotype weed in the Southern Highlands area, they have made some determinations of variability. Thus, the male heads had in flourished time average size 14.6-15.1 mm / 7.0-7.5 mm, with or without fruits (achenes). Females flowerhead (capitula) were $25.4 \mathrm{~mm} / 8.8 \mathrm{~mm}$ and formed 22 achenes. Female clones had fruits $2.29 \mathrm{~mm}$ length, thickness $0.65 \mathrm{~mm}$ and $20.5 \mathrm{~mm}$ pappus. Some correlations obtained were positive and significant: between flowerhead dimensions $r=$ $0.375 * * *$ and $0.265 * *$ in male populations and $r=0.278 *$ the female population. Negative correlation was obtained between the sizes of the female clones fruits, $r=-0.037$. The present study demonstrated cross-type structure evolved in these conditions and wide possibilities that it has spread throughout the agricultural field.
\end{abstract}

Keywords: achenes, $C$. arvense, diversity, flowerheads/ capitula, male and female clones.

\section{INTRODUCTION}

Cirsium arvense (L.) Scop. (Pro syn. Cnicus arvensis Hoffm., Serratula arvensis L, Canadian thistle, perennial thistle, field thistle, CIRAR- Bayer code) is a perennial dicotyledonous (Moore, 1975; Gustavsson, 1994; American Flora, 2006), dioecious with male and female flowers, which are formed on different plants (Lloyd \& Myall, 1976; Lalonde \& Roitberg, 1994). The female flowers (pistillate) differ from the male (staminate) by the absence of pollen [abundant in male flowers (Kenneth, 1972)], the distinct smell of vanilla and smaller dimensions of corolla lobs- 2.8 $\mathrm{mm}$ vs $4.8 \mathrm{~mm}$. The female flowers have larger pappus: $23 \mathrm{~mm}$ vs $11 \mathrm{~mm}$, and larger involucre: 19 $\mathrm{mm}$ vs $13 \mathrm{~mm}$. Male flowers rich in pollen evolved from an initial gynodioic population and exist in three forms (Kay, 1985): some with pollen and without fruits, other subhermaphordites with small fruit sets (1-10), and the third hermaphrodites with greater than 10 fruit sets (Figure 1). From the recent research it has been found that the hermaphrodite clone (have male and female flowers on the same plant) is about $26 \%$ of male plants, capable of producing achenes. In the UK $15 \%$ of male flowers are hermaphrodites and produce 2-10 achenes/ flowerhead. The hermaphrodites resemble with typical male flowers. The incidence of hermaphroditism varies by location. Clones and individual strains can be also imperfectly dioecious. Except hermaphrodites, C. arvense flowers are 
obliged out-crossers (Bureš, 2010). The flowers are by the way exclusively insect-pollinated (Ellis \& Ellis-Adam, 1992). Of the 350 species of the Cirsium genus, insects prefer $C$. arvense due to the "accessibility of its copious nectar" (Van Der Kooi et al, 2015). Chromosome number for all Cirsium arvense varieties is $2 \mathrm{n}=34$.

Flowerhead looks specific with flowers- corolla pink or purple. Flowers (florets) from a flowerhead are similar. Small flowers are closed in heads/ capitula, which is 1.0-1.5 cm in diameter and 1.3-1.5 $\mathrm{cm}$ tall. Flower color varies from lavender to pink or white. Flowers lasts for a long enough period. Stigmata are receptive for 3-8 days when pollen is abundant and 5 other days when pollen availability is lower. Achene fruit set depend on pollen (Ionescu and Ionescu, 2012). In addition the male and female plants are close, pollination is high and decreases when the distance is over $50 \mathrm{~m}$. The fruits (achene type) were 2.5-3.2 mm length and of $1.0 \mathrm{~mm}$ in diameter. Their color is brown shades. Achenes weight depends on ecotype, being $0.67-1.52 \mathrm{mg} / \mathrm{seed}$, with an average of $1.08 \mathrm{mg}$. After training achenes still need 8-10 days to become sufficient mature to be able to germinate.

In recent years there has been a quantitative analysis on the structure of existing ecotype. It took into account the morphological characteristics of the reproductive organs of the plant $C$. arvense scattered in different crops. Determinations took place in two periods. At flowering were measured length and width of the heads. At maturity analyzed the number of achenes formed in each flowerhead, along with achenes dimensions (length and width). In female flowerhead measured pappus length.

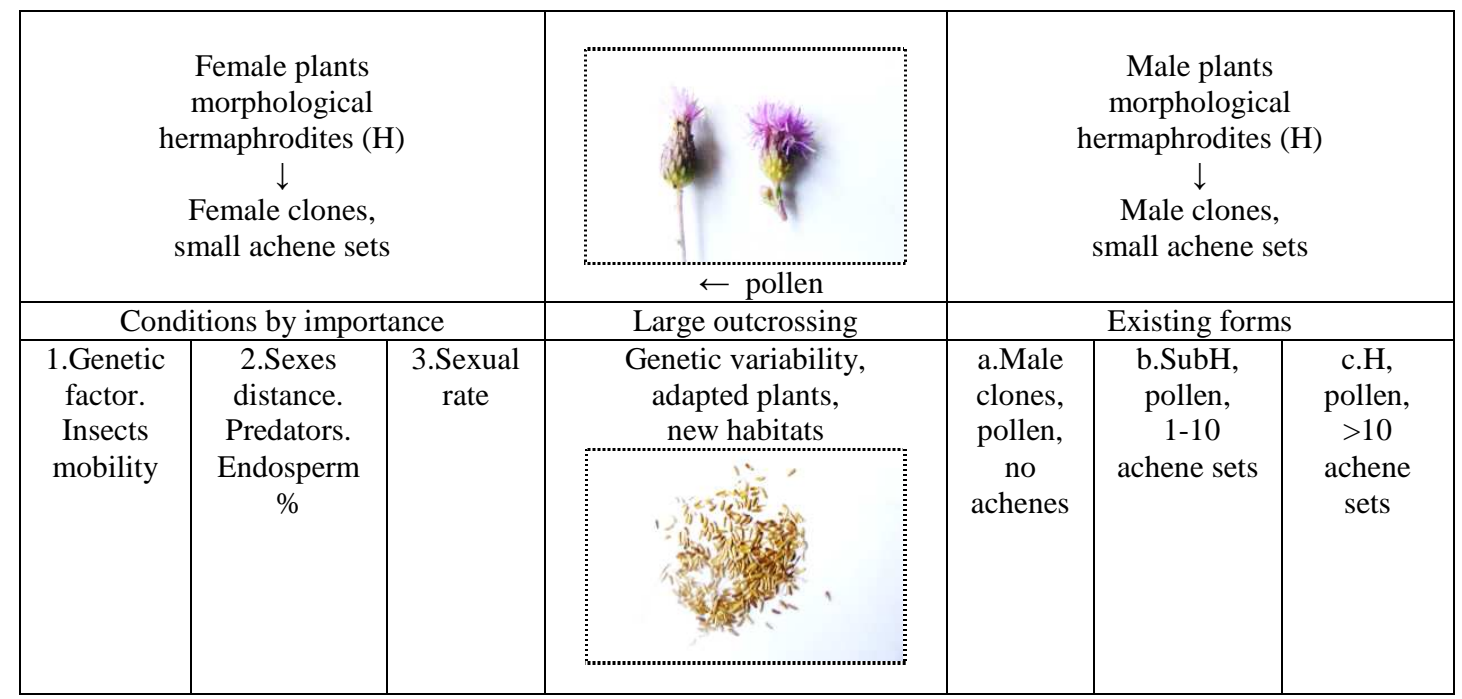

Figure 1. Mating Dioecious System (MDS) of Cirsium arvense weed

\section{MATERIALS AND METHODS}

Measurements were carried out in July last two years (2016-2018). C. arvense plants analyzed were found in different areas of local farms with natural weeding. Studied area was located in the perimeter of Albota, Argeş County. In flowering stage were measured with ruler the $C$. arvense flowerhead by length and width both male and female clones. After three weeks after flowering, were harvested mature heads. The method consisted by passing in zig-zag through large fireplaces, developed weed without a guided positioning. Thus they were collected by 100 heads each of two male populations and 100 heads of female population. The distance between populations was from close to $50 \mathrm{~m}$. The samples were brought to the laboratory for maturing and determinations. After 
15 days of harvest was considered that the fruits were swept and were measured the number of achenes/ male heads. The female heads were measured achene no., achene length and width, and pappus length. The data shown represents the average of the measurements made.

Measured morphological characters were analyzed by three directions. The first direction was the establishment of morphological variability, with the model of polygons frequency (\%), or histograms. The method allows the expression in several ways: i) modal values (highest frequencies), ii) trends and extremes characters, iii) the specifics of each character expressed. Among the analyzed characters were established some correlations, by which they could observe and study their tendencies within ecotype. The expressions values was used Excel. Another direction was variance analysis of data obtained from measurements. Statistical parameters used were: i) $\overline{\mathrm{a}}=\frac{\Sigma \mathrm{x}}{n}$, where $\overline{\mathrm{a}}=$ media, $\mathrm{x}=$ values, ii) $\mathrm{S}^{2}$ (variance) $=\frac{1}{n-1}\left[\Sigma x^{2}-\frac{(\Sigma x)^{2}}{n}\right]$, iii) $\mathrm{S}$ (standard error) $=\sqrt{S^{2}}$ and iv) $S \%$ (variation coefficient) $=\frac{s}{a} 100$. Finally it has developed a comparative study synthesis of flowers and fruits characters variability of $C$. arvense.

\section{RESULTS AND DISCUSSIONS}

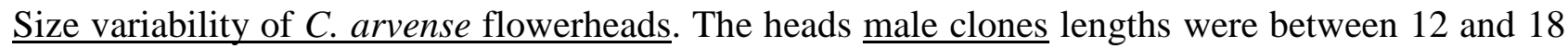
$\mathrm{mm}$ ( $a$ population) (figure 2 ).

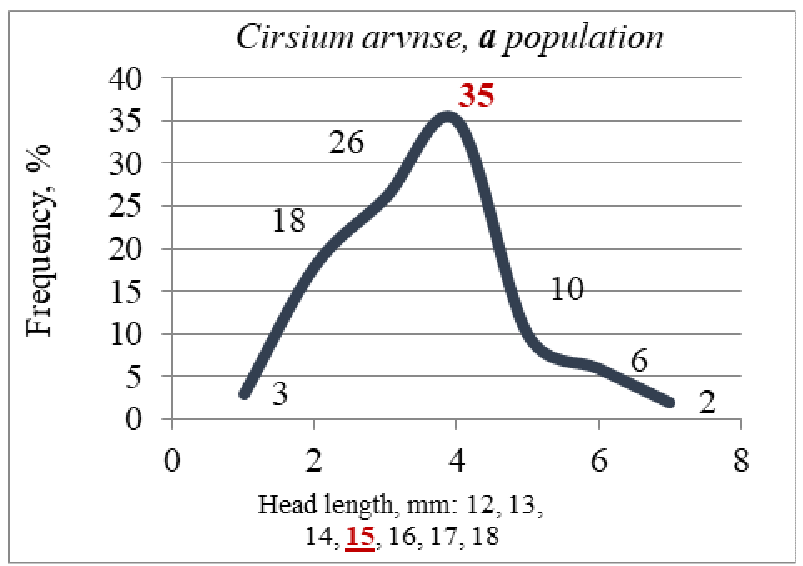

Figure 2. Length frequencies of C.arvense male capitula, a population

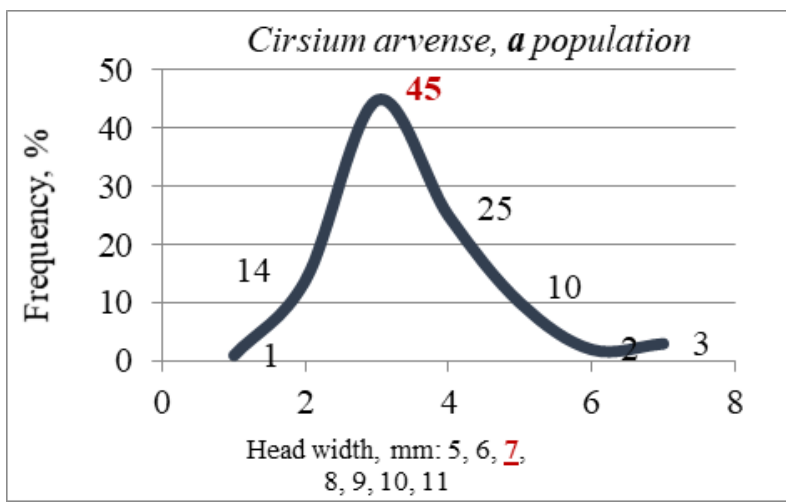

Figure 3. Thickness frequencies of C.arvense male capitula, a population 
The highest frequencies were $15 \mathrm{~mm}(35 \%)$, followed by the $14 \mathrm{~mm}(26 \%)$ and $13 \mathrm{~mm}(18 \%)$. Extreme lengths represented 5\% of the total. The width of the heads was scored between 5 and 11

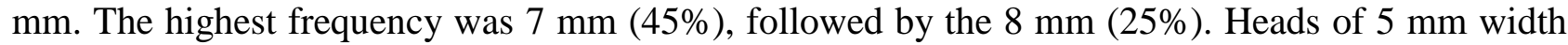
was only $1 \%$ (figure 3 ).

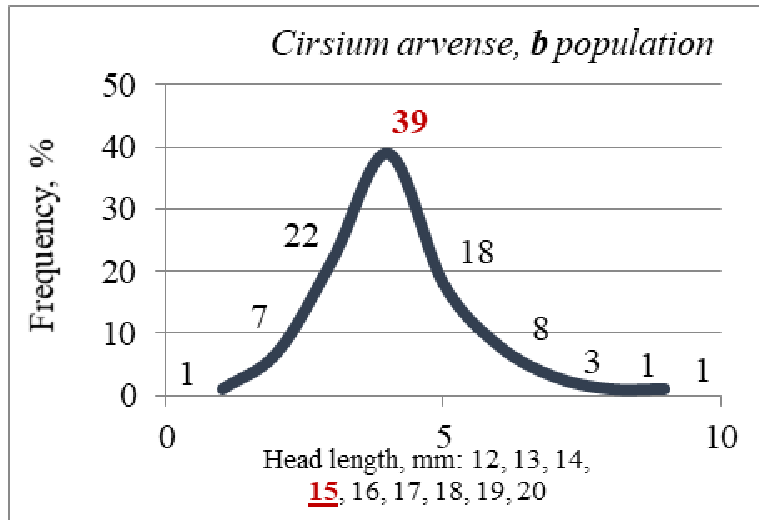

Figure 4. Length frequencies of C.arvense male capitula, $\underline{b}$ population

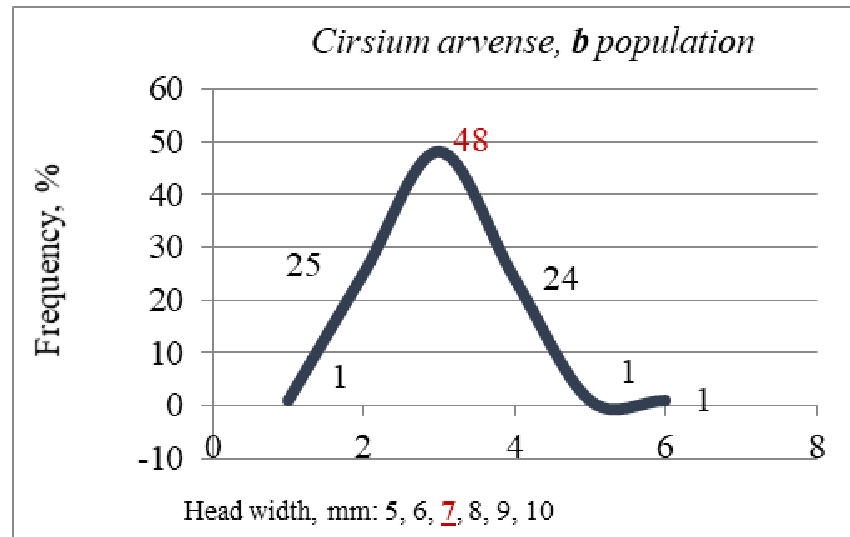

Fig. 5. Thickness frequencies of C.arvense male capitula, $\underline{b}$ population

Male clones of $b$ population have had the heads between 12 and $20 \mathrm{~mm}$, with greater frequency to $15 \mathrm{~cm}(39 \%)$. Extremes accounted for $5 \%$ (figure 4). Head width was 5-10 mm with the modal value of $7 \mathrm{~mm} \mathrm{(48 \% ),} \mathrm{and} \mathrm{the} \mathrm{measurements} \mathrm{of} \mathrm{extremes} \mathrm{represented} 3 \%$ of the total (figure 5).

Flowering takes place in long day conditions (figures 6 and 7). With some exceptions the ecotypes are necessary between 14-16 hours of light during the day. For 14 hour light is needed a daily temperature little higher. In our conditions, in July is 14 to 15 hours day light, with an average of temperature of $21^{\circ} \mathrm{C}$.

Correlations between the two dimensions obtained show positive result, upwards. Thus, the $a$ population the provision of statistical point of view was clearly evident, $r=0.375^{* * *}$ (figure 8). Data for $b$ population were similar, increasing and distinct significant, $\mathrm{r}=0.265^{* * *}$. Variability of $a$ population was slightly higher, while the $b$ population was grouped. The relationships obtained show that under the existing conditions weeds that produced the longest heads had larger thickness (figure 9). 


\section{Current Trends in Natural Sciences}

Vol. 9, Issue 17, pp. 38-51, 2020

https://doi.org/10.47068/ctns.2020.v9i17.005

Current Trends in Natural Sciences (on-line)

ISSN: 2284-953X

Current Trends in Natural Sciences (CD-Rom)

ISSN: 2284-9521

ISSN-L: 2284-9521

ISSN-L: 2284-9521

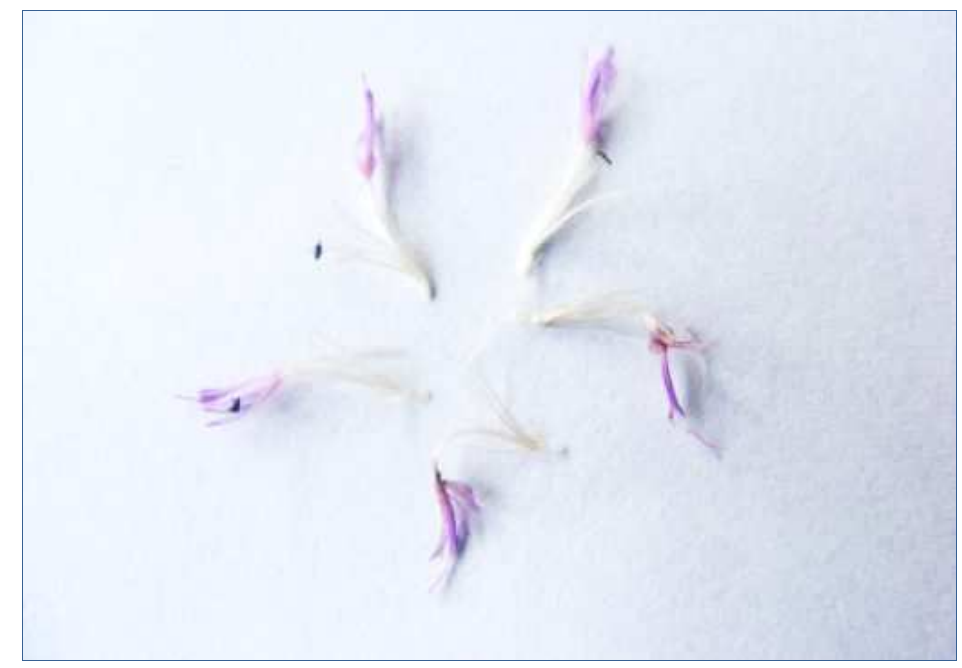

Figure 6. Male flowers, staminate

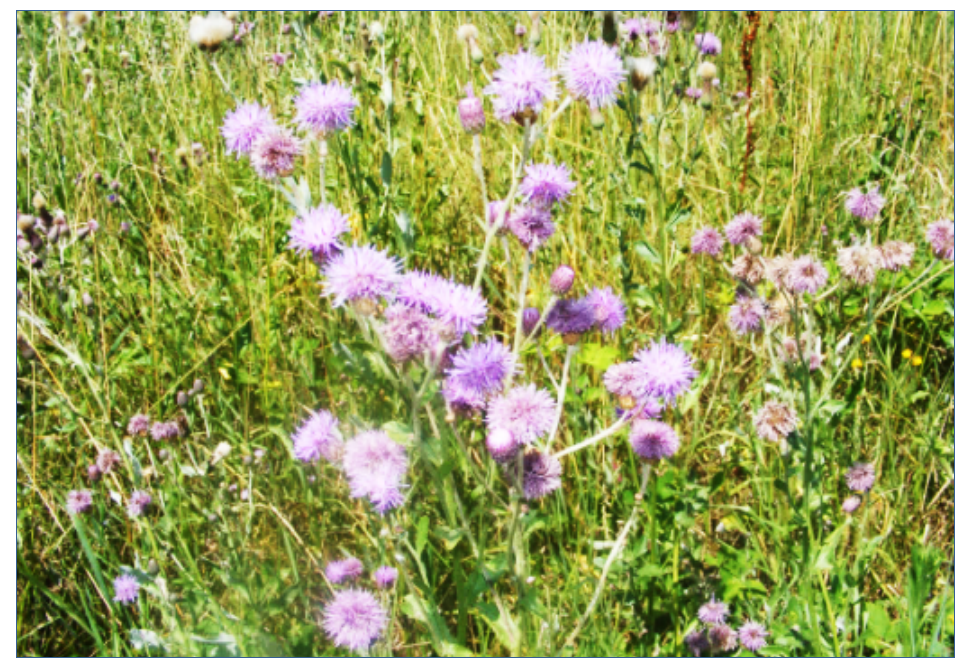

Figure 7. Capitula from male clones of C. arvense weed

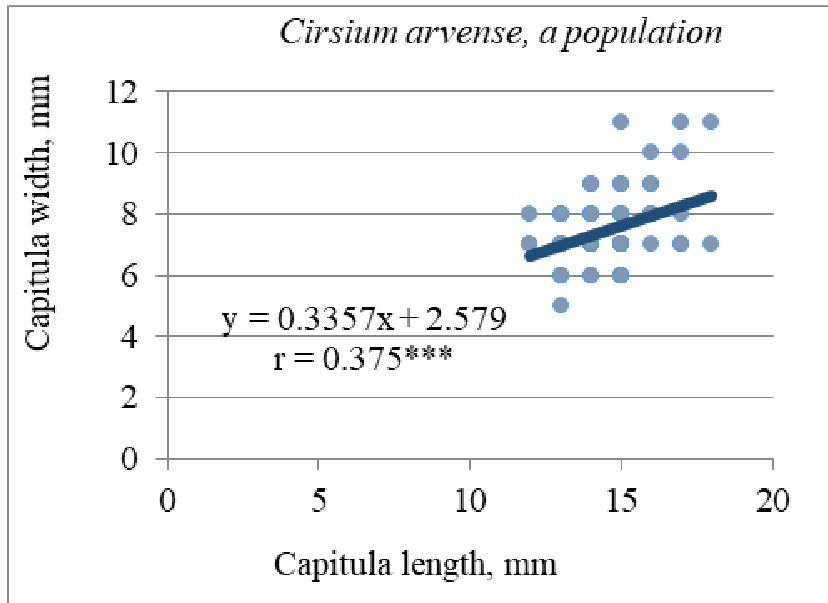

Figure 8. Correlation between male capitula dimensions of C. arvense, population a 


\section{Current Trends in Natural Sciences}

Vol. 9, Issue 17, pp. 38-51, 2020

https://doi.org/10.47068/ctns.2020.v9i17.005

Size of the female heads variability was different and specific (figure 10). Thus the heads length was between 18 and $36 \mathrm{~mm}$, with the highest frequency from 27 to $29 \mathrm{~mm}(43 \%)$. This was followed by the lengths of $30-32 \mathrm{~mm}$ at a rate of $23 \%$ and $19 \%$ of 24 to $26 \mathrm{~mm}$. The extremes were only $2 \%$. Head width ranged from 6 to $13 \mathrm{~mm}$. Greater frequencies of capitulas had a $10 \mathrm{~mm}$ (26\%), followed by the $9 \mathrm{~mm}(23 \%)$ (figure 11).

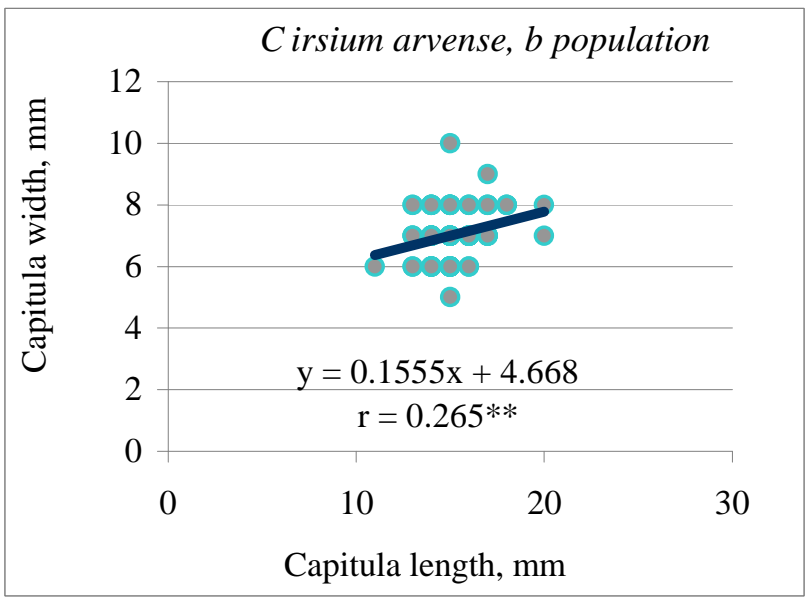

Figure 9. Correlation between male capitula dimensions of C. arvense, population $\underline{b}$

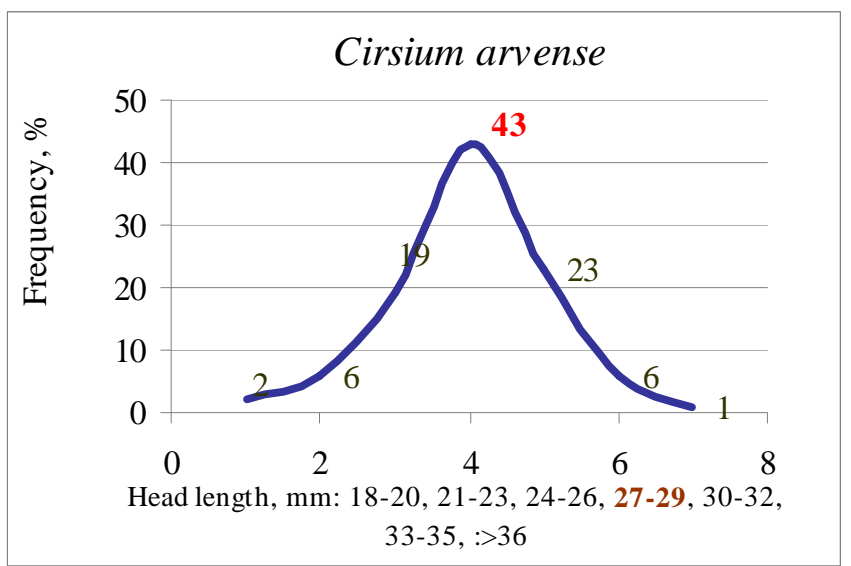

Figure 10. Length frequencies of C.arvense female capitula

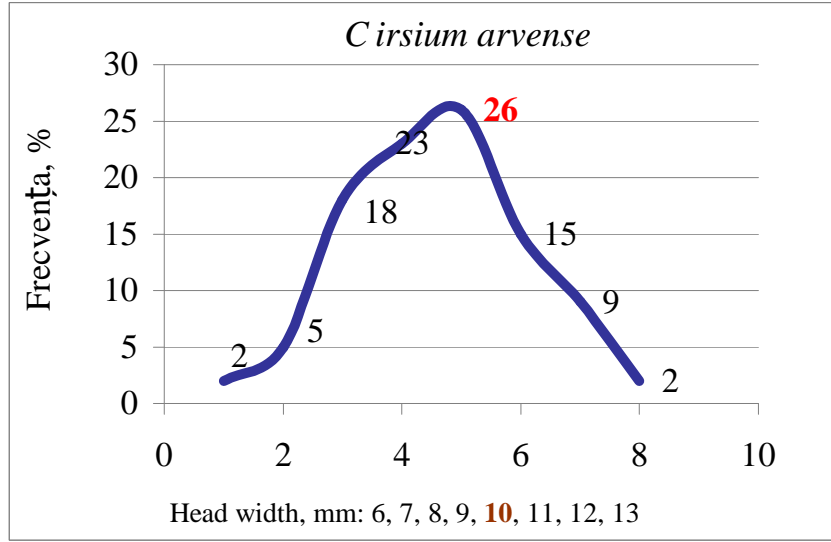

Figure 11. Thickness frequencies of C. arvense female capitula 


\section{Current Trends in Natural Sciences}

Vol. 9, Issue 17, pp. 38-51, 2020

https://doi.org/10.47068/ctns.2020.v9i17.005

Current Trends in Natural Sciences (on-line)

ISSN: 2284-953X

Current Trends in Natural Sciences (CD-Rom)

ISSN: 2284-9521

ISSN-L: 2284-9521

ISSN-L: 2284-9521

Number of flowers (florets) in every head varies by clone. This can form between 100-4 30 and even 1120 into a capitula. Appearance of the blooming heads of female clones showing some morphological differences, visible in the field. Generally their flowering period is identical to that of male clones (figures 12 and 13).

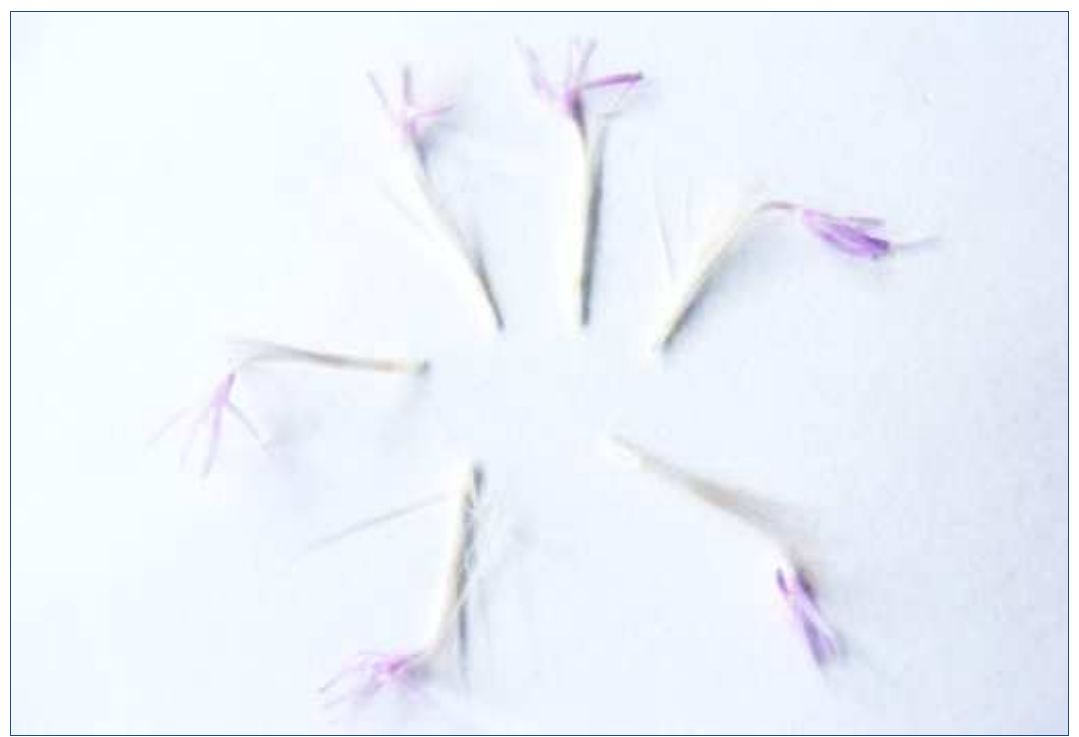

Figure 12. Female flowers, pistillate.

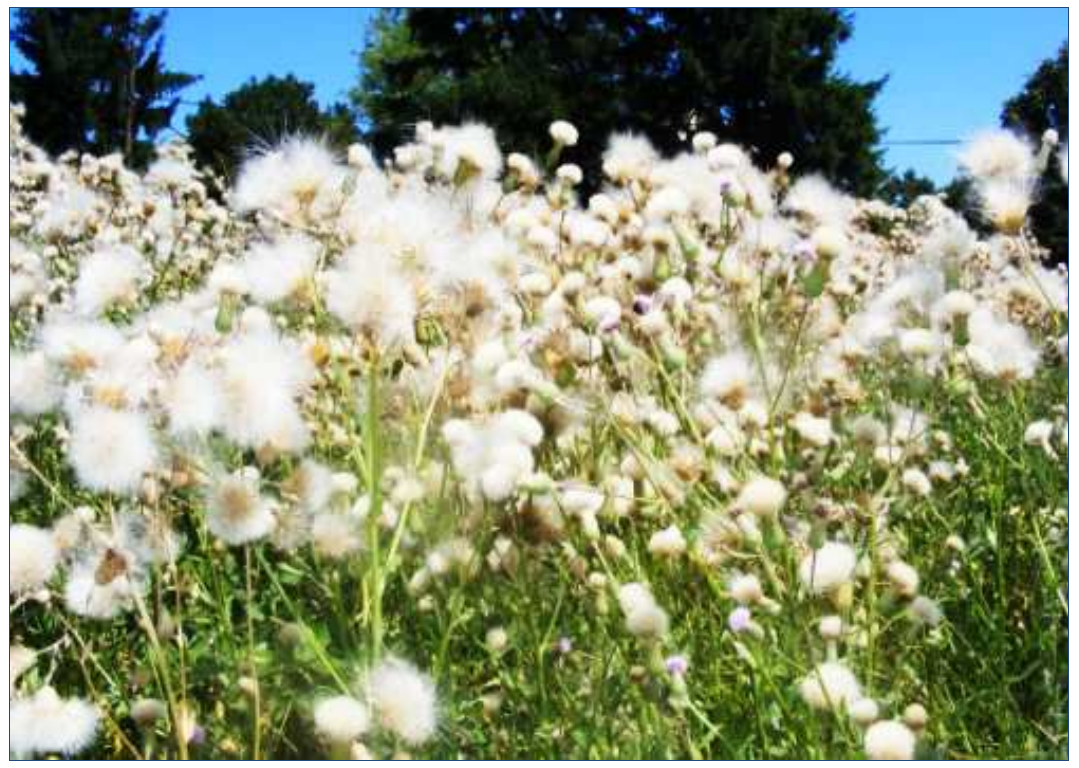

Figure 13. Capitula from female clones of C.arvense weed

Achene structure sets of $C$. arvense male clones. Among the populations analyzed was chosen two different structural characters. Thus, the first population which $99 \%$ of heads were formed only pollen, and $1 \%$ of heads formed two achenes, like subhermaphrodite (table 1). Second population structure was more complex. $78 \%$ were producing pollen, $21 \%$ formed 1-9 subhermephordites achehes, in $1 \%$ of heads were 13 achenes as hermaphrodites. 
Current Trends in Natural Sciences

Vol. 9, Issue 17, pp. 38-51, 2020

https://doi.org/10.47068/ctns.2020.v9i17.005

Current Trends in Natural Sciences (on-line)

ISSN: 2284-953X

ISSN-L: 2284-952
Current Trends in Natural Sciences (CD-Rom)

ISSN: 2284-9521

ISSN-L: 2284-9521

Table 1. Structure of achene sets from male clones (\%)

\begin{tabular}{|c|c|c|c|}
\hline Clones type & $\begin{array}{c}\text { No. } \\
\text { achenes }\end{array}$ & $\begin{array}{c}\text { Population } \\
\text { A, } \%\end{array}$ & $\begin{array}{c}\text { Population } \\
\text { B, \% }\end{array}$ \\
\hline Pollen, no achene & 0 & 99 & 78 \\
\hline \multirow{3}{*}{$\begin{array}{c}\text { Subhermafrodites, pollen, } \\
\text { achene 1-10 sets }\end{array}$} & 1 & - & 8 \\
\cline { 2 - 4 } & 2 & 1 & 3 \\
\cline { 2 - 4 } & 3 & - & 4 \\
\cline { 2 - 4 } & 4 & - & 1 \\
\cline { 2 - 4 } & 6 & - & 4 \\
\cline { 2 - 4 } & 9 & - & 1 \\
\hline Hermafrodites, polen, achene $>10$ sets & 13 & - & 1 \\
\hline
\end{tabular}

Variability of $C$. arvense female clones achenes. The heads of the female clones produce fruits like achenes type in a variable number (figure 14). In terms of field grown on average 59 may be formed/ head. Values obtained show limits between 3 and 72 pieces/ head. The highest frequency was obtained from 13 to 22 fruits/ head (29\%), followed by one with 23-32 fruits/ head (25\%), and 3-12 fruits/ head (22\%). The set with 72 pieces/ head accounted for $1 \%$ of the total. Achenes aspect is specific (figure 15).

Achenes had specific size variability. So long it had limits between $2.0 \mathrm{~mm}$ and $3.3 \mathrm{~mm}$. Frequency distribution was discontinuous (figure 16). Thus the maximum values were in the $2.4-2.5 \mathrm{~mm}$ (24\%) and 2.8-2.9 $\mathrm{mm}(24 \%)$. Values of over $3.0 \mathrm{~mm}$ of the length of the achenes were only $5 \%$. The width of the fruits followed the same uneven distribution curve. The amount of modal was obtained as $0.6 \mathrm{~mm}(26 \%)$ and $0.8 \mathrm{~mm}(26 \%)$. Fruit with $0.4 \mathrm{~mm}$ was only $1 \%$ (figure 17). Pappus length of female heads is considered somewhat long as that of male flowers. Pappus from female heads ranged between $17 \mathrm{~mm}$ and $31 \mathrm{~mm}$ (figure 18). High frequencies of pappus had flowers of 20-22 $\mathrm{mm}(41 \%)$ and $23-25 \mathrm{~mm}(46 \%)$. The longest pappus with $29-31 \mathrm{~mm}$ accounted for only 1 $\%$. Into the field female flowerheads are expressed by a compact mass whitish falls off by the wind (figure 19). Male pappus remains common between dry petals.

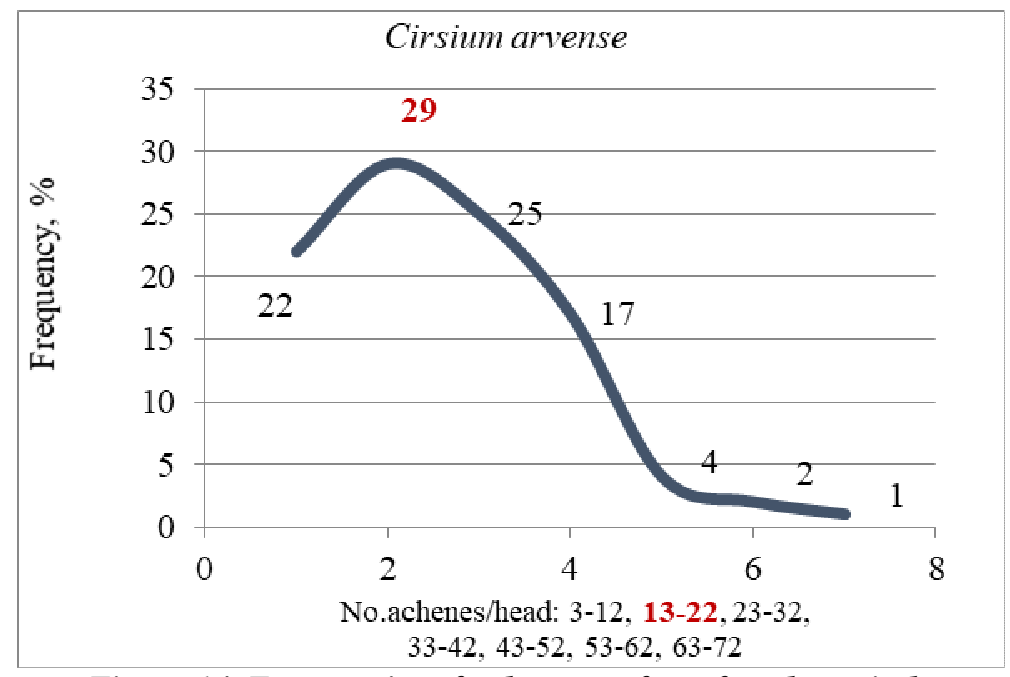

Figure 14. Frequencies of achene no. from female capitula 


\section{Current Trends in Natural Sciences}

Vol. 9, Issue 17, pp. 38-51, 2020

https://doi.org/10.47068/ctns.2020.v9i17.005

Current Trends in Natural Sciences (on-line)

ISSN: 2284-953X

Current Trends in Natural Sciences (CD-Rom)

ISSN: 2284-9521

ISSN-L: 2284-952

ISSN-L: 2284-9521

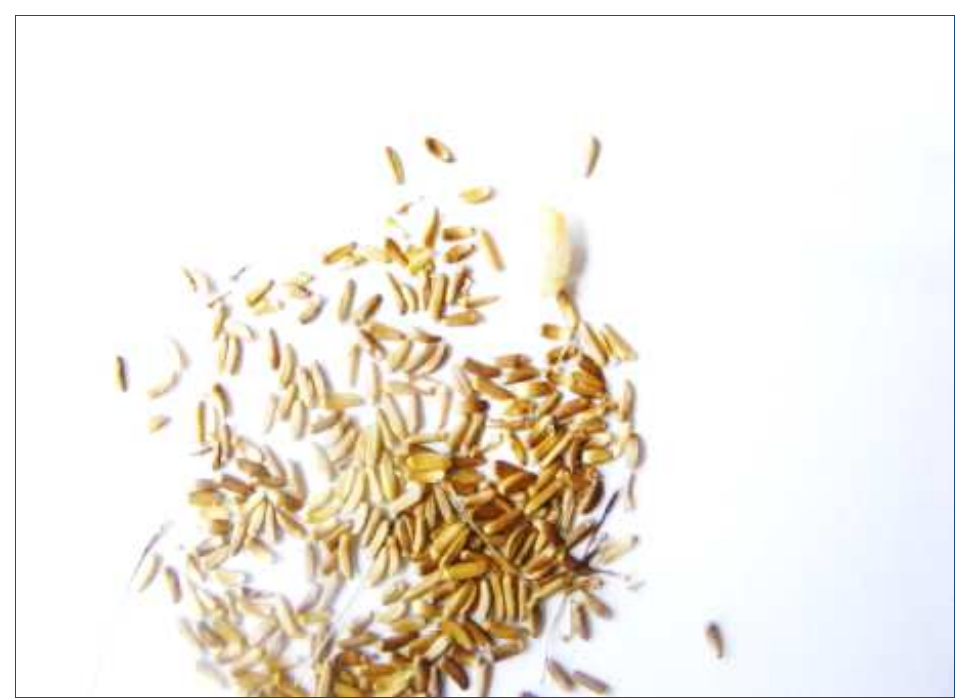

Figure 15. Fruits/ achenes of female head, general aspect

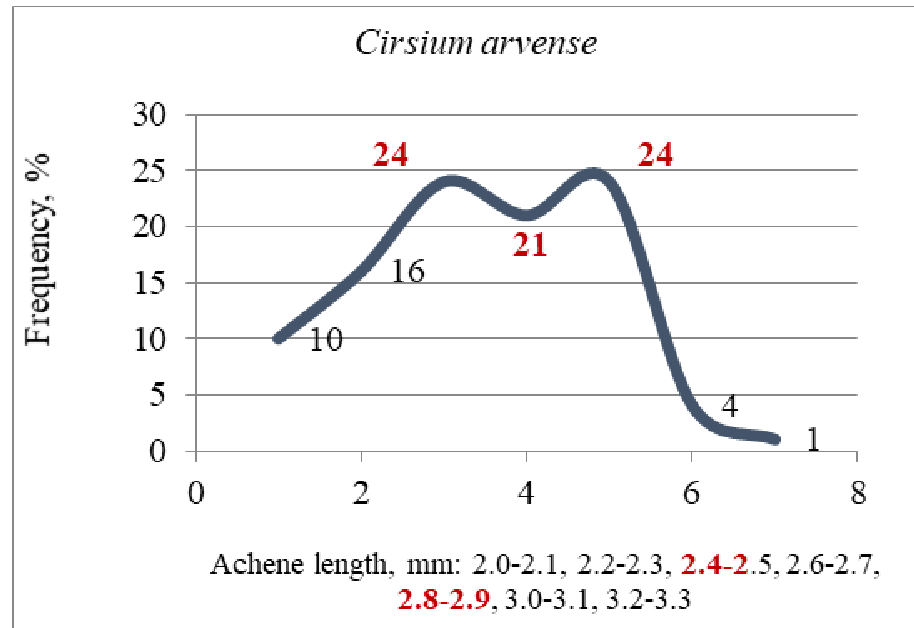

Figure 16. Frequencies of achene length from female fruits, C.arvense weed

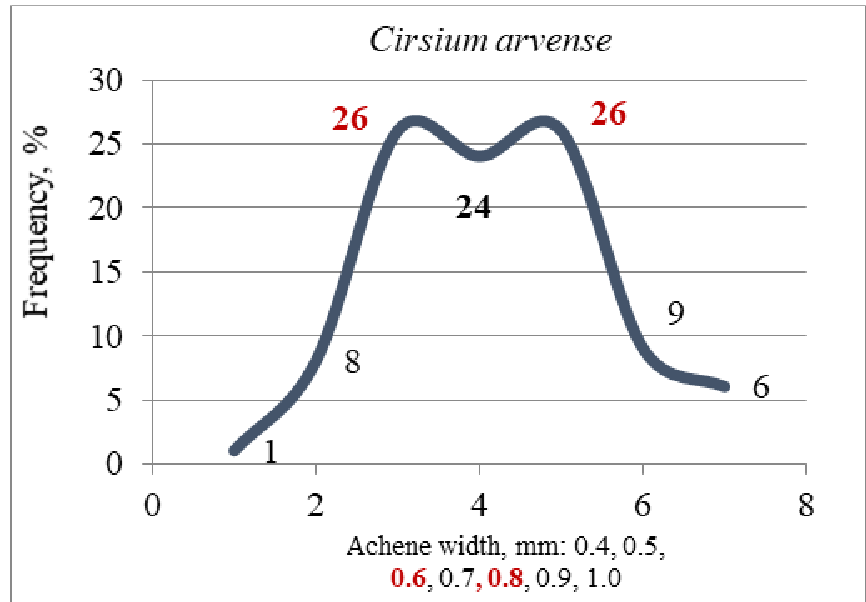

Figure 17. Frequencies of achene width from female fruits, C.arvense weed 


\section{Current Trends in Natural Sciences}

Vol. 9, Issue 17, pp. 38-51, 2020

https://doi.org/10.47068/ctns.2020.v9i17.005

Current Trends in Natural Sciences (on-line)

ISSN: 2284-953X

Current Trends in Natural Sciences (CD-Rom)

ISSN: 2284-9521

ISSN-L: 2284-952

ISSN-L: 2284-9521

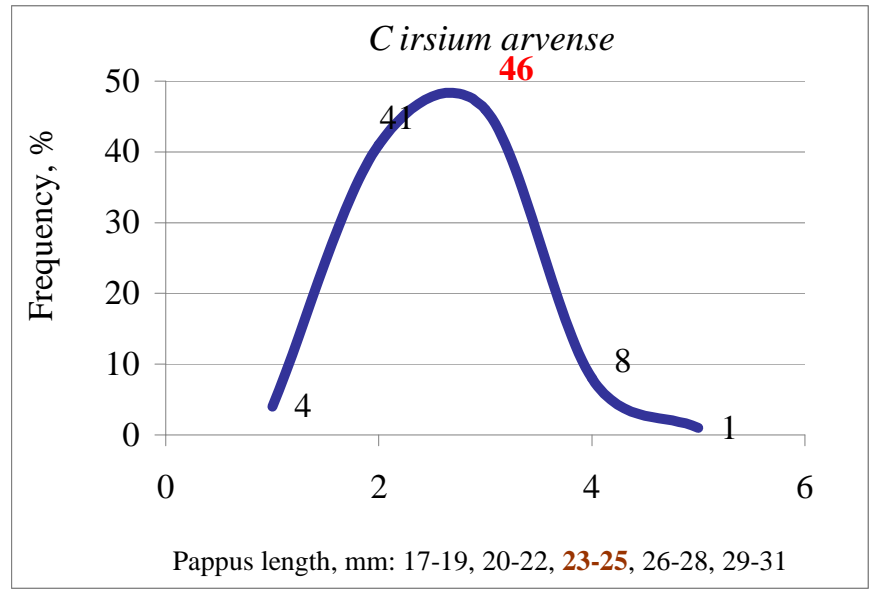

Figure 18. Frequencies of female pappus length.

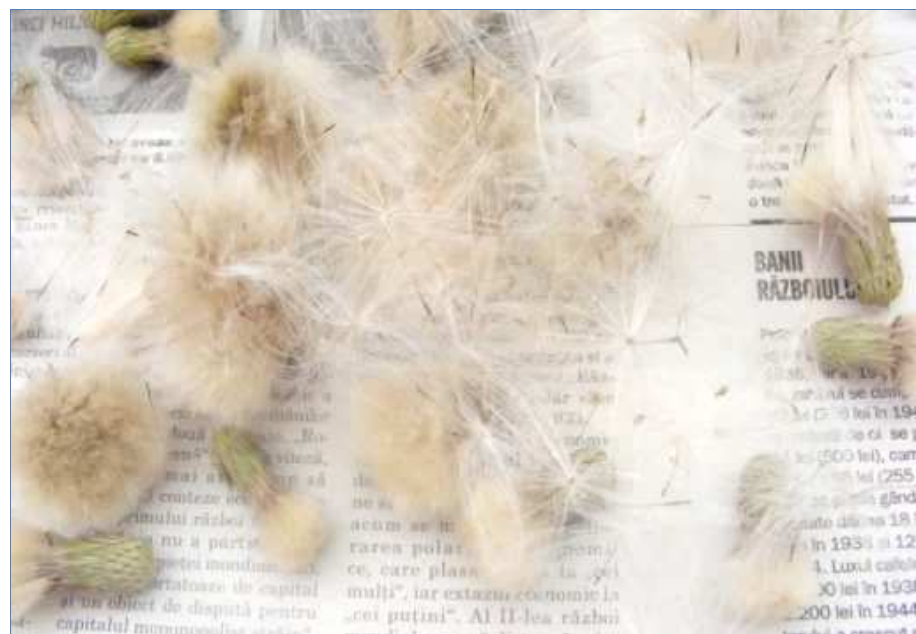

Figure 19. The pappus from female capitulum

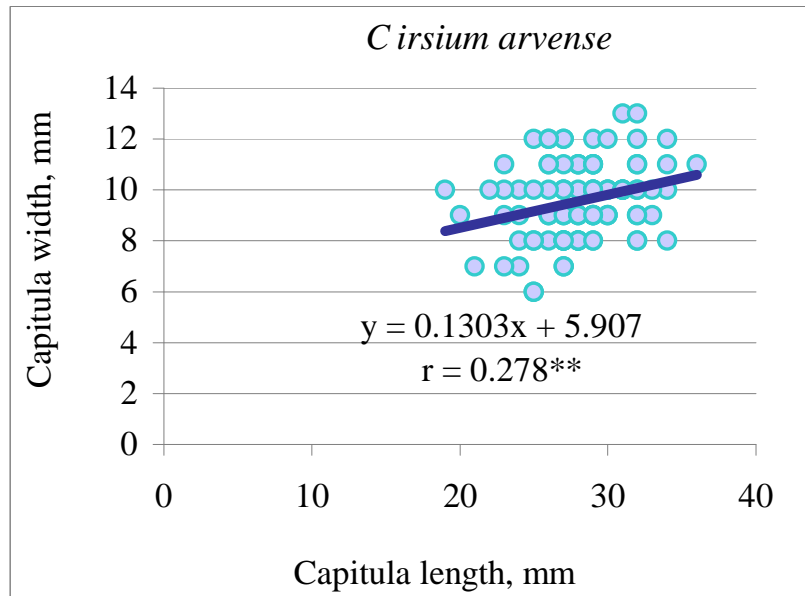

Figure 20. Correlations between capitula dimensions, female heads 


\section{Current Trends in Natural Sciences}

Vol. 9, Issue 17, pp. 38-51, 2020

https://doi.org/10.47068/ctns.2020.v9i17.005

Current Trends in Natural Sciences (on-line)

ISSN: 2284-953X

Current Trends in Natural Sciences (CD-Rom)

ISSN: 2284-9521

ISSN-L: 2284-9521

ISSN-L: 2284-9521

Correlations obtained between female characters showed different aspects (Figure 20). Between length and width of head obtained o positive and positive correlation with $\mathrm{r}=0.278^{* *}$. Between length and width of achenes correlation shows negative trend $(r=-0.037)$, insignificant. It follows that the length of the achenes was less dependent on the width, it being possible for the two sizes to be practically independent (figure 21).

Between a number of achenes from a head and length were obtained positive and significant correlation, $r=0.226^{*}$. If the heads formed more fruits, so their length was greater (figure 22 ). The cause may be the environment that living conditions were more favorable.

The correlation between the pappus length and achene length has negative trend, $r=-0.0023$, close to zero. Conclusion: pappus is formed regardless of the achene length.

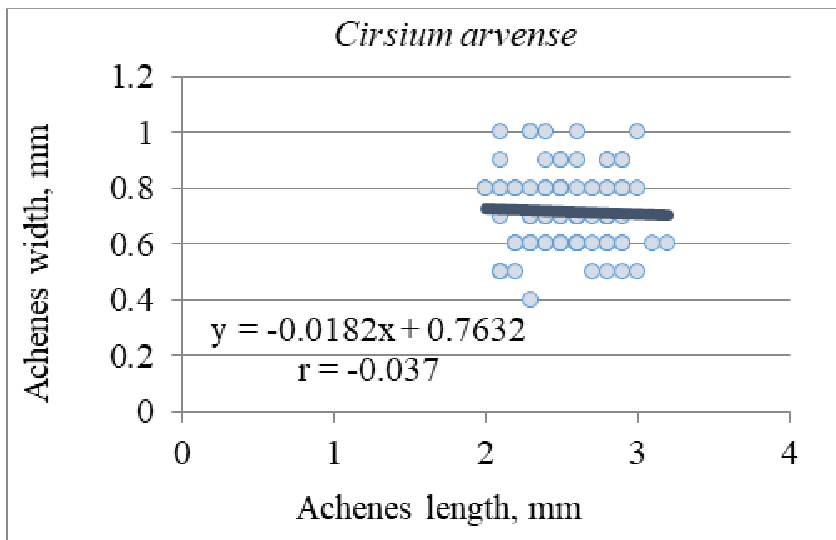

Figure 21. Correlations between achenes dimensions, female heads

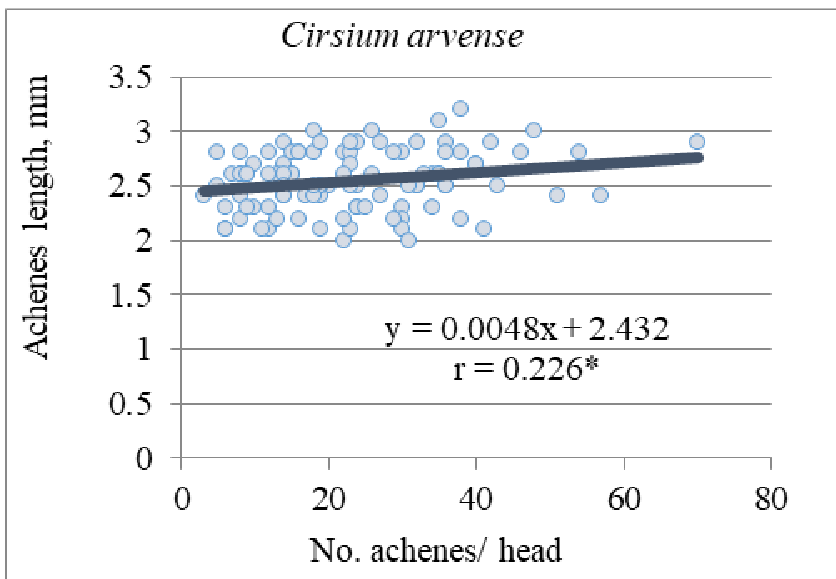

Figure 22. Correlations between no.achenes/capitula with achene length

In general, the whole situation emerged very favourable correlations between the capitula length with pappus length $(\mathrm{r}=0.368 * * *)$ and between capitula width with total number of achenes $(\mathrm{r}=$ $0.412 * * *)$ (table 2). Negative correlation were reached between achene dimensions $(\mathrm{r}=-0.037)$, and between achene length and pappus length $(\mathrm{r}=-0.0023)$. 
Current Trends in Natural Sciences

Vol. 9, Issue 17, pp. 38-51, 2020

https://doi.org/10.47068/ctns.2020.v9i17.005

Current Trends in Natural Sciences (on-line)

ISSN: 2284-953X

ISSN-L: 2284-9521
Current Trends in Natural Sciences (CD-Rom)

ISSN: 2284-9521

ISSN-L: 2284-9521

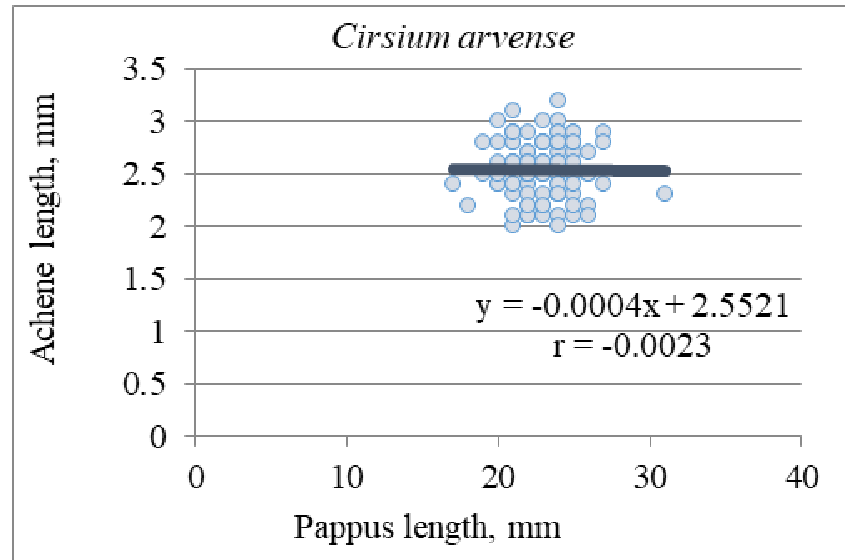

Figure 23. Correlations between pappus length with achene length

Table 2. Correlations between female fruits character of C.arvense

\begin{tabular}{|c|l|l|l|l|l|l|}
\hline Character & $\begin{array}{c}\text { Capitula } \\
\text { length }\end{array}$ & $\begin{array}{c}\text { Capitula } \\
\text { width }\end{array}$ & $\begin{array}{c}\text { No. } \\
\text { achenes }\end{array}$ & $\begin{array}{c}\text { Achene } \\
\text { length }\end{array}$ & $\begin{array}{c}\text { Achene } \\
\text { width }\end{array}$ & $\begin{array}{c}\text { Pappus } \\
\text { length }\end{array}$ \\
\hline Capitula length & 1 & $0.278^{* *}$ & $0.254^{* *}$ & 0.014 & 0.175 & $\mathbf{0 . 3 6 8} * * *$ \\
\hline Capitula width & & 1 & $\mathbf{0 . 4 1 2} * * *$ & 0.162 & $0.256^{* *}$ & 0.071 \\
\hline No. achenes & & 1 & $0.226 *$ & 0.079 & 0.167 \\
\hline Achene length & & & 1 & $\mathbf{- 0 . 0 3 7}$ & $\mathbf{- 0 . 0 0 2 3}$ \\
\hline Achene width & & & & 1 & 0.006 \\
\hline Pappus length & & & & 1 \\
\hline
\end{tabular}

Statistical analysis of the flowerhead and fruits characters. Data obtained that could express the specific way in which weed was adapted in agricultural field of the South, may be typical. Thus, the length of male heads was $14-15 \mathrm{~mm}$ with a width of $7 \mathrm{~mm}$. Female capitula were $25 \mathrm{~mm}$ in length and $8-9 \mathrm{~mm}$ in width (table 3 and 4). Achene number of female head was 21-22, with length average of $2.3 \mathrm{~mm}$ and $0.6-0.7 \mathrm{~mm}$ width. Pappus had 20-21 mm length.

Table 3. Statistic indices of Cirsium arvense (L)Scop. fruits. A. Male capitula

\begin{tabular}{|c|c|c|c|c|}
\hline \multirow{2}{*}{ Indices } & \multicolumn{2}{|c|}{ Male heads, population a } & \multicolumn{2}{c|}{ Male heads, population b } \\
\cline { 2 - 5 } & Length, $\mathrm{mm}$ & Width, $\mathrm{mm}$ & Length, $\mathrm{mm}$ & Width, $\mathrm{mm}$ \\
\hline Mean, $\overline{\mathrm{a}}$ & $\mathbf{1 4 . 5 7}$ & $\mathbf{7 . 4 7}$ & $\mathbf{1 5 . 1 3}$ & $\mathbf{7 . 0 2}$ \\
\hline Variance, $\mathrm{s}^{2}$ & 1.601 & 1.282 & 1.932 & 0.666 \\
\hline Standard error, $\mathrm{s}$ & 1.265 & 1.132 & 1.3901 & 0.8162 \\
\hline Variation coef., $\%$ & $\mathbf{8 . 6 8}$ & $\mathbf{1 5 . 1 5}$ & $\mathbf{8 . 6 5}$ & $\mathbf{1 1 . 6 3}$ \\
\hline
\end{tabular}

Table 4. Statistic indices of Cirsium arvense (L)Scop. fruits. B. Female capitula

\begin{tabular}{|c|c|c|c|c|c|c|}
\hline \multirow{2}{*}{ Indices } & \multicolumn{2}{|c|}{ Heads/ capitula } & \multicolumn{3}{c|}{ Fruits/ achene } & $\begin{array}{c}\text { Pappus } \\
\text { length, } \\
\text { mm }\end{array}$ \\
\cline { 2 - 6 } & $\begin{array}{c}\text { Length, } \\
\text { mm }\end{array}$ & $\begin{array}{c}\text { Width, } \\
\text { mm }\end{array}$ & No./head & $\begin{array}{c}\text { Length, } \\
\text { mm }\end{array}$ & $\begin{array}{c}\text { Width, } \\
\text { mm }\end{array}$ & \begin{tabular}{c}
$\mathbf{2 0 . 4 8}$ \\
\hline Mean, $\bar{a}$
\end{tabular} \\
$\mathbf{2 5 . 4 1}$ & $\mathbf{8 . 7 7}$ & $\mathbf{2 1 . 6 1}$ & $\mathbf{2 . 2 9 2}$ & $\mathbf{0 . 6 5 1}$ & 110.635 \\
\hline Variance, $\mathrm{s}^{2}$ & 156.78 & 17.39 & 257.49 & 1.306 & 0.109 & 10.518 \\
\hline Standard error, s & 12.521 & 4.170 & 16.047 & 1.143 & 0.331 & 10.51 \\
\hline Variation coef., \% & $\mathbf{4 9 . 2 8}$ & $\mathbf{4 7 . 5 5}$ & $\mathbf{7 4 . 2 6}$ & $\mathbf{4 9 . 8 7}$ & $\mathbf{5 0 . 8 4}$ & $\mathbf{5 1 . 3 6}$ \\
\hline
\end{tabular}

The variation coefficient (VC,\%) was low: 8-15\% for male head dimensions, and big- bigger for all female parameters (head and fruit achene type). In general, the diversity of flowers and fruits of $C$. 
arvense characters dressed specific issues, possibly by adapting on this type of soil from southern territory.

\section{CONCLUSIONS}

A common species that cause significant damage of crops is C.arvense ( $L)$ Scop. The weed is widespread in the southern territory, because this ecotype may be vell adapted by its special biology. In order to control through proper management is good to know as it's special reproduction system and as many characters. It was found that a species expressing widest variability may find it easier means of control and stop eventually. Morphological variability, especially reproductive, being less known, could express eco-existing type here.

Table 5. Mean values of Cirsium arvense $($ L) Scop. weed fruits character
\begin{tabular}{|c|l|c|c|}
\hline \multicolumn{2}{|c|}{ Fruits characters } & Literature & Research \\
\hline \multirow{2}{*}{ Headflower length, mm } & male & $13-15$ & $12-18$ \\
\cline { 2 - 4 } & female & $13-15$ & $19-36$ \\
\hline \multirow{2}{*}{ Headflower width, mm } & male & $10-15$ & $5-11$ \\
\cline { 2 - 4 } & female & $10-15$ & $6-13$ \\
\hline \multirow{2}{*}{$\begin{array}{c}\text { No.achenes/ } \\
\text { headflower }\end{array}$} & male & $4-6$ & $0-13$ \\
\cline { 2 - 4 } & female & $40-59$ & $3-70$ \\
\hline \multicolumn{2}{|c|}{ Achene length, mm } & $2.5-3.2$ & $2.0-3.2$ \\
\hline \multicolumn{2}{|c|}{ Achene width, mm } & $0.9-1.0$ & $0.4-1.0$ \\
\hline Achene weight, mg & $0.67-1.52$ & - \\
\hline Female pappus length/ mm & - & $17-31$ \\
\hline
\end{tabular}

We have had $C$. arvense capitula a little longer length, and a little short width (table 5). Another determined characters were: male achenes no./capitulul express 1\% subhermaphrodite by $99 \%$ without fruits for population a, and 1\% hermaphrodites, $21 \%$ sufhermaphrodites, $78 \%$ without fruits by population b. From female capitulul the achenes were with dimensions little shorter, and the papus length with $17-31 \mathrm{~mm}$.

\section{REFERENCES}

Berner D.K. (2013). Successful establishment of epiphytotics of Puccinia punctiformis for biological control of Cirsium arvense. Biological Control, 67, 350-360.

Berner D.K. (2015). Asymptomatic systemic disease of Canada thistle (Cirsium arvense) caused by Puccinia punctiformis and changes in shoot density following inoculation. Biological Control, 86, 28-35.

Bureš P. (2010). Pollen viability and natural hybridization of Central European species of Cirsium. Presalia, 82, 391422.

Donald W.W. (1994). Geostatistics for mapping weeds, with Canada thistle (Cirsium arvense) patch as a case study. Weed Science, 42, 648-657.

Ellis W.N. and Ellis-Adam A.C. (1992). Flower visits to Cirsium and Carduus. Entomologische Berichten, Amsterdam, $52,137-140$.

Everitt J.H., Lonard R.L., Little C.R. (2007). Weeds in South Texas and Northern Mexico. Lubbock Texas Tech University Press, ISBN 0-89672-614-2.

French R.C., Lightfield A.R. (1990). Induction of Systemic Aecial Infection in Canada Thistle (Cirsium arvense) byTeliospores of Puccinia punctiformis. Phytopathology, 8(8), 872-877.

Gustavsson A.M.D. (1994). Canada thistle occurrence and biology. Vaxtskyddsnotiser, 58(3), 79-84.

Hunter J.H. (1996). Control of Canada thistle (Cirsium arvense) with glyphosate applied at the bud vs. rosette stage. Weed Science, 44, 934-938.

Ionescu N., Ionescu S.-G. (2012). Study about seed-set flower head variation betwwen populations of Canadian thistle (Cirsium arvense). Annals of Craiova University, Agriculture \& Horticulture, 17(53), 705-710. 


\section{Current Trends in Natural Sciences}

Vol. 9, Issue 17, pp. 38-51, 2020

https://doi.org/10.47068/ctns.2020.v9i17.005

Current Trends in Natural Sciences (on-line)

Kay Q.O.N. (1985). Hermaphrodites and subhermaphrodites in a reputedly dioecious plant, Cirsium arvense (L.) Scop. New Phytologist, 100, 457- 472.

Kenneth R.S. (1972). Some Observations on the Evolution of Pollen Types in Dicotyledons. New Phytologist, 71(1), 181- 185.

Lalonde R.G. and Roitberg B.D. (1994). Mating system, life-history, and reproduction in Canada thistle (Cirsium arvense; Asteraceae). American Journal of Botany, 81, 21- 28.

Lloyd D. And Myall A.J. (1976). Sexual dimorphism in Cirsium arvense (L.) Scop. Annals of Botany, 40, $115-123$.

Moore R.J. (1975). The biology of Canadian weeds. 13: Cirsium arvense (L.) Scop. Canadian Journal of Plant Science, 55, 1033- 1048.

Van Der Kooi C.J., Pen I., Staal M., Stavenga D.G., Elzenga J.T.M. (2015). Competition for pollinators and intracommunal spectral dissimilarity of flowers. Plant Biology, 2: 10.1111/plb. 12328.

Zimdahl R.L. and Foster G. (1993). Canada thistle (Cirsium arvense) control with discing and herbicides. Weed Technology, 7, 146- 149.

xxx) Flora of North America, (2006). Magnoliophyta: Asteridae, 6 part: Asteraceae. Oxford University Press, New York, 19, 1- 24. 